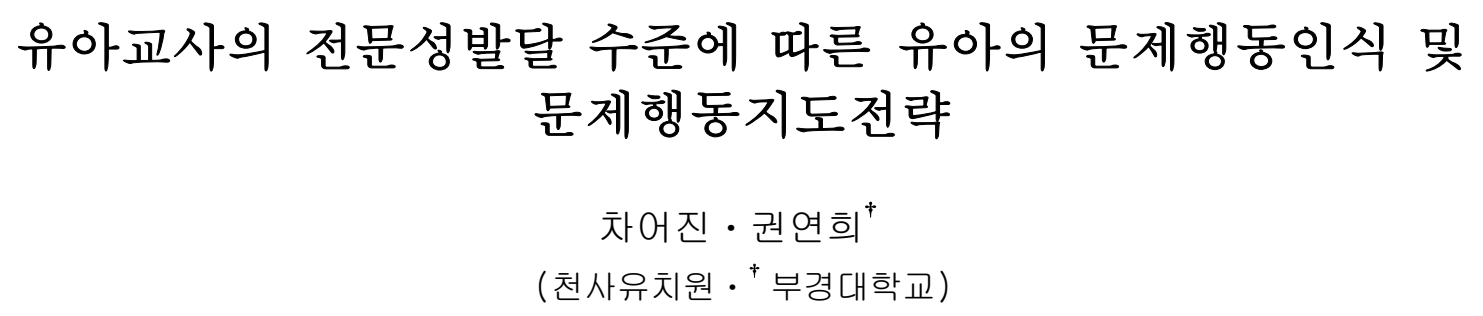

\title{
The Cognition and Strategy of Preschool Teacher About Child's Behavior Problem According to the Level of Teacher's Professional Development
}

\author{
Eo-Jin CHA $\cdot$ Yeon-Hee $\mathrm{KWON}^{\dagger}$ \\ (Angel Kindergarden $\cdot{ }^{\dagger}$ Pukyong National University)
}

\begin{abstract}
This study examined the relationships between the cognitions and strategies of child's problem behaviors depending on the level of preschool teacher's professional development. Participants were 176 preschool teachers in B Metropolitan city. The teachers completed rating scales to measure teacher's professional development, the perception of child's problem behaviors, and teacher's guiding strategies for child's problem behaviors. The collected data were analyzed using descriptive statistics, one-way ANOVA, and Pearson correlations. Results showed that there were different cognitions of child's problem behaviors depending on the level of teacher's professional development. Secondly, child's problem behavior guiding strategies by the level of teacher's professional development were significant differences in the positive prevention strategy I, II, and the positive reaction strategy. Finally, there were somewhat different relationship between the cognition of child's problem behaviors and the problem behavior guiding strategies according to the level of teacher's professional development. Findings are discussed in terms of the importance of teacher's professional development in the context of teacher's education planning for teacher's guiding strategy about preschooler's problem behavior.
\end{abstract}

Key words : Teacher's professional development, Cognition of child's problem behavior, Strategy of child's problem behavior

\section{I. 서 론}

유아의 문제행동이란 그 연령 수준에서 하지 말아야 할 행동을 하거나 행동을 과도하게 또는
상황에 맞지 않게 하는 것을 의미한다(김광웅, 2002). 선행연구들에 따르면, 유아기에 이러한 문 제행동을 많이 보인 경우 이후 발달 단계에서 부 적응 행동을 더 많이 보일뿐 아니라 반사회적 행

† Corresponding author : 051-629-5498, yeonheekwon@pknu.ac.kr 
동 및 비사회적 행동을 초래할 가능성이 높으 며, 사회정서적 발달뿐 아니라 인지적 발달에도 부정적인 영향을 나타내었다(강현경.조형숙, 2008; 김현정, 2000; Qi \& Kaiser, 2003). 강정원과 이경 민(2006)은 문제행동을 하는 유아를 그대로 방치 하게 되면 학령기에 학습장애, 자아존중감 저하 로 말미암은 사회성 발달장애 등으로 발전하게 되며, 이로 인해 문제행동이 심화되고 치료 또한 어려워지게 된다고 하였다. 이 같은 선행연구에 서 알 수 있듯이 문제행동의 발현에 있어 조기개 입이 중요하며, 이는 유아기 문제행동지도에 대 한 연구의 중요성을 시사해 준다.

유아기 문제행동지도의 중요성이 강조되면서 먼저 유아의 어떠한 행동이 문제행동이며 이러한 문제행동을 어떻게 발견할 것인지에 대한 관심이 높아지게 되었으며, 문제행동진단에는 평소 유아 를 관찰하고 평가할 수 있는 성인의 보고가 중요 함이 제안되었다(김영아.이진·김유진·김민영·오경자, 2011). 이는 유아와 긴 시간을 보내는 성인의 관 찰은 유아에 대한 많은 정보를 담고 있을 뿐 아 니라 유아를 바라보는 시각자체가 유아를 대하는 태도에도 영향을 미칠 수 있다는 것이다. 이러한 관점에서 볼 때 유아와 많은 시간을 보내는 교사 가 유아의 여러 가지 부적절한 행동을 얼마나 문 제라고 인식하는지에 따라서 교사의 유아에 대한 태도, 행동에 대한 지도 전략 등이 달라질 수 있 을 것이다.

더욱이 최근 맞벌이 부부가 늘어나고 영유아의 조기교육에 대한 관심이 증가함에 따라 유아가 교육기관에 취원하는 연령이 하향화 되고, 유아 교육기관에서 보내는 시간이 점차 길어지면서 유 아에 대한 교사 평가의 중요성이 커지고 있다(신 미숙, 2004). 교사는 학급 내에서 유아에게 큰 영 향을 제공할 수 있고, 유아들을 직접 관찰할 수 있는 위치에 있기 때문에 유아의 문제행동을 진 단하고 교정할 뿐 아니라 예방에도 지속적인 관 심을 가져야 할 것이다(김준규·박희숙·추성경, 2005; 김현정, 2000).
이처럼 유아의 문제행동을 지도하는데 있어서 교사의 역할은 어느 누구보다 중요하다고 하겠 다. 문제행동에 대한 교사의 지도전략은 문제가 일어나기 전에 사용되는 예방적 전략과 문제행동 이 일어난 이후에 사용되는 반응적 전략으로 분 류된다(김연하, 2007). 예방적 전략은 문제행동이 일어나기 전에 교사가 미리 철저한 계획을 세우 고, 유아의 행동관찰을 통해 문제를 일으킬만한 환경을 정비함으로써 예측할 수 있는 문제행동을 막고, 보다 적절한 대처행동을 제시함으로써 문 제행동을 사전에 예방하는 것이다(Lewis, Colvin, \& Sugai, 2000; Smith, 2004). 특히 몇몇 연구 (Fox, Dunlap, \& Powell, 2002; VanDerHeyden, Witt, \& Gatti, 2001)를 통해 유아의 문제행동에 대한 예방적 차원의 긍정적 행동지원 전략의 효 과가 지지되면서 유아의 문제행동에 대한 교사의 예방적 지도전략에 대한 관심이 높아졌다.

한편, 유아의 문제행동에 대한 반응적 전략은 문제행동이 일어난 후에 교사가 개입하는 것으로 그 내용에 따라 긍정적 반응전략과 부정적 반응 전략으로 구분된다(김연하, 2007). 긍정적 반응전 략은 유아가 바람직한 행동이나 사회적 기술을 습득할 수 있도록 돕는 방법이며, 부정적 반응전 략은 유아의 문제행동에 초점을 두고 부정적인 피드백이나 처벌을 통해 그 문제 행동이 다시 일 어나지 않도록 하는 지도 전략을 의미한다. 부정 적 반응전략은 유아의 문제행동을 잠시 동안 멈 추게 하는 효과를 나타낼 수 있지만 그 문제행동 을 대신할 만큼 긍정적이고 대안적인 행동들을 배울 수 없기 때문에 문제행동이 다시 유발될 가 능성이 높다(김경숙, 2008). 따라서 유아에게 미 치는 장기적 효과를 생각할 때 교사는 문제행동 을 지도할 때 예방적 지도전략과 긍정적 지도전 략을 사용하는 것이 바람직할 것이다. 하지만, 아 직까지 유아교사가 구체적으로 어떠한 문제행동 지도전략을 사용하고 있으며, 교사의 문제행동 지도전략의 차이가 어떠한 요인에 의해서 비롯되 는지를 예방적 차원과 반응적 차원의 지도전략을 
모두 포함하여 살펴본 연구는 상대적으로 부족하 다.

지금까지 유아교사의 문제행동지도전략에 대해 서는 주로 학력 및 경력(권혜영, 2006; 임우정, 2005), 연령(강미라, 2005) 등과 같은 사회 인구학 적 변인에 따른 차이를 보거나 교사개인의 효능 감(김지영, 2002), 유아의 문제행동에 대한 교사 인식(김경숙, 2008)과 같은 교사개인적 요인과의 관계가 주로 연구되어왔다. 특히 김경숙(2008)은 교사의 문제행동 지도전략이 유아의 문제행동에 대한 교사의 인식에 따라 달라질 것이라고 보고, 이 둘 간의 상관관계를 살펴보았다. 연구결과, 교 사가 유아의 문제행동을 발달의 한 측면으로 이 해하거나 환경과의 문제로 인식하게 되면 그 행 동의 문제정도를 심각하게 인식하지 않을 수 있 으며 보다 긍정적 지도전략을 사용하게 된다고 하였다. 반면, 교사가 유아의 문제행동을 유아자 체의 문제로 인식할 경우, 그 행동의 문제정도를 심각하게 인식하여 이를 소거하기 위한 부정적 지도전략을 사용하게 된다고 하였다. 하지만, 김 경숙(2008)의 연구는 유아의 문제행동에 대한 인 식과 반응적 지도전략과의 관련성만을 살펴봄으 로써 예방적 차원의 문제행동 지도전략에 대해서 는 살펴보지 못하였다. 앞서 살펴본 것과 같이 문제행동지도에서 예방적 차원의 긍정적 행동지 도의 중요성(Fox et al., 2002; VanDerHeyden et al., 2001)을 고려할 때, 유아교사의 문제행동인식 과 지도전략 간의 관계를 포괄적으로 이해하기 위해서는 예방적 차원의 지도전략을 포함한 연구 가 필요하다.

한편, 교직은 전문직으로 다양한 역량이 요구 되고(성병창.부재율·한경임.이경화, 2009), 유아교 사는 교직을 수행함에 있어서 발달과정을 거치게 된다(조부경·백은주, 2004). 유아교사의 발달은 유 능한 교사에게 요구되는 전문성영역을 중심으로 발달수준을 구분하는데(박은혜, 2009), 교사의 전 문성 발달수준에 따라 역할수행능력에 차이가 있 는 것으로 나타났다(김지연, 1997; 성병창, 2007).
유아교사에게 있어 문제행동지도가 중요한 교사 역할 중 하나임을 고려해 볼 때, 유아교사의 전 문성발달 수준에 따라서 교사가 사용하는 문제행 동지도전략이 차이가 있을 것으로 예상해 볼 수 있다. 하지만, 유아교사의 전문성발달수준에 따라 서 문제행동지도전략이 어떻게 다른지를 살펴본 연구는 부족한 편이다.

교육의 질은 교사의 질을 능가할 수 없고 양질 의 유아교육을 지향할 때 교사의 전문성 발달수 준이 주안점이 된다는 김선희와 백은주(2010)의 지적을 고려할 때, 유아교사의 전문성 발달수준 은 유아가 보이는 문제행동에 대한 교사의 인식, 교사의 문제행동지도전략에 차이를 가져올 것으 로 예상해 볼 수 있다. 하지만 아직까지 유아교 사의 전문성 발달수준을 고려하여 유아의 문제행 동에 대한 인식 및 교사의 문제행동 지도전략을 알아본 연구는 거의 없다. 이에 본 연구에서는 유아교사의 전문성 발달수준에 따라 유아의 문제 행동을 어떻게 인식하고 있으며 또한 어떠한 문 제행동지도전략을 모색하는지를 알아보고자 하였 다. 더 나아가 유아교사의 전문성 발달수준에 따 라 문제행동인식 및 지도전략 간의 상관관계가 어떠한지를 알아보고자 하였다. 이는 유아교사의 문제행동지도전략에 대한 포괄적이고 구체적인 이해를 가져다 줄 것이며, 유아의 문제행동지도 와 관련된 교사교육 프로그램을 개발에 기초적 자료를 제공할 것이다. 이 같은 연구의 목적과 필요성에 기초하여 선정된 연구문제는 다음과 같 다.

1. 유아교사의 전문성발달 수준에 따라 유아의 문제행동인식에 차이가 있는가?

2. 유아교사의 전문성발달수준에 따라 유아의 문제행동지도 전략에 차이가 있는가?

3. 유아교사의 전문성발달수준에 따라 유아의 문제행동에 대한 인식과 문제행동지도전략 의 상관관계는 어떠한가? 


\section{II. 연구 방법}

\section{1. 연구대상}

본 연구는 $\mathrm{B}$ 지역에 근무하고 있는 유치원과 어린이집의 만3세 이상 학급의 담임교사 176 명을 대상으로 하였다. 영유아의 발달적 특성에 따라 해당 행동을 문제행동이라고 보는 교사의 인식에 차이가 있을 수 있으므로 영아반을 제외한 만 3 세 이상 학급의 담임교사를 대상으로 하였다.

연구대상 선정을 위해 1차적으로 유치원 18곳 과 어린이집 6곳의 만 3 세 이상의 학급을 담당하 고 있는 교사 300 명에게 유아교사의 전문성 발달 수준에 대한 설문지를 의뢰하였고 이중 268부가 회수되었다. 유아교사의 전문성발달수준에 따른 유아문제행동인식 및 문제행동지도전략의 차이를 보기 위하여 회수된 268명의 자료에 대하여 전문 성 발달수준의 총점을 기준으로 상, 하위 $33 \%$ 에 해당되는 유아교사 176 명을 최종 선정하였다.

연구대상의 일반적인 특징을 살펴보면, <표 1> 에 제시된 것과 같이 유아교사의 $2 / 3$ 정도는 유치 원(60.2\%)에 근무하고 있으며, 교사 연령은 $2 / 3$ 이 상이 20 대(72.7\%)였고, 절반이 약간 넘는 교사

<표 1> 연구대상의 일반적 특징 $\quad(\mathrm{N}=176)$

\begin{tabular}{|c|c|c|c|}
\hline 변인 & 구분 & 빈도 & $\%$ \\
\hline \multirow{2}{*}{ 근무기관 } & 유치원 & 106 & 60.2 \\
\hline & 어린이집 & 70 & 39.8 \\
\hline \multirow{3}{*}{ 교사연령 } & 24세 이하 & 38 & 21.6 \\
\hline & 25 29세 이하 & 90 & 51.1 \\
\hline & 30세 이상 & 48 & 27.3 \\
\hline \multirow{2}{*}{ 학력 } & 전문대졸 & 111 & 63.1 \\
\hline & 대졸 이상 & 65 & 36.9 \\
\hline \multirow{4}{*}{ 교직경력 } & 3년 이하 & 61 & 34.7 \\
\hline & $4 \sim 6$ 년 이하 & 70 & 39.8 \\
\hline & 7 9년 이하 & 25 & 14.2 \\
\hline & 10년 이상 & 20 & 11.3 \\
\hline \multirow{3}{*}{$\begin{array}{l}\text { 담당학급 } \\
\text { 유아연령 }\end{array}$} & 만3세 & 65 & 36.9 \\
\hline & 만4세 & 58 & 33.0 \\
\hline & 만5세 & 53 & 30.1 \\
\hline \multicolumn{2}{|r|}{ 합계 } & 176 & 100.0 \\
\hline
\end{tabular}

$(63.1 \%)$ 가 전문대졸의 학력을 가지고 있었다. 교 직경력은 4년 6년이하가 $39.8 \%$, 3년이하 $34.7 \% 7$ 년 9년이하 $14.2 \%, 10$ 년이상이 $11.3 \%$ 순으로 나타 났고, 담당학급 유아의 연령은 3세반이 $36.9 \%, 4$ 세반 $33.0 \%, 5$ 세반 $30.1 \%$ 로 대체로 고루 분포되 었다.

\section{2. 연구도구}

가. 유아교사의 전문성 발달수준

본 연구에서 유아교사의 전문성 발달수준을 측 정하기 위하여 백은주와 조부경(2004)의 '유치원 교사의 전문성 발달수준에 대한 평가척도'를 사 용하였다. 본 도구는 유아교사의 전문성 발달 수 준에 대하여 물리적 환경구성, 교육과정 계획, 실 시 등에 대한 전문성발달 수준을 알아보는 '지식 과 기술 발달' 영역, 교사로서의 자신에 대한 태 도 등을 알아보는 '자기이해 발달' 영역, 동료교 사, 부모와의 관계 등과 관련된 '생태적 발달' 영 역의 세가지 하위영역으로 구성된 총 55 문항의 자기보고식 척도이다. '전혀 그렇지 않다(1점)' ‘매우 그렇다(5점)'로 이루어진 5점 평점척도로 점수가 높을수록 교사는 해당 영역의 내용에 대 하여 교사로서 전문성 발달수준이 높다고 인식하 는 것을 의미한다. 내적 합치도 Cronbach's $\alpha$ 계 수에 의한 유아교사의 전문성 발달수준 척도의 총점 및 하위영역별 신뢰도 계수는 '지식과 기술 의 발달' .91, '자기 이해의 발달' .91, '생태적 발 달'이 .91 이며, 교사의 전문성 발달 전체는 .96으 로 대체로 높은 편이였다.

나. 유아의 문제행동에 대한 교사 인식 유아 문제행동에 대한 교사의 인식을 알아보기 위해서 김경숙(2008)이 번안하여 사용한 $\mathrm{Essa(1988)}$ 의 '유아 문제행동 척도'를 사용하였다. 본 도구 는 유아의 문제행동에 대하여 크게 공격적·반사 회적 행동, 방해하는 행동, 파괴적 행동, 감정적. 의존적 행동, 사회적 활동의 기피의 5 가지 행동 유형으로 살펴보고 있으며, 각 행동들에 대하여 
교사가 얼마나 문제라고 생각하는지에 대한 인식 정도를 알아보고자 하였다. 총 35 문항으로 교사 는 각 문항의 내용에 대하여 '전혀 문제가 되지 않는다(1점)' ‘매우 문제가 된다(5점)’의 5점 척 도로 평정하였다.

하위 영역별 점수의 범위는 공격적·반사회적 행동 8 40점, 방해하는 행동 5 25점, 파괴적 행 동 5 25점, 감정적·의존적 행동 9 45점, 사회적 활동의 기피 8 40점으로 이루어진다. 내적 합치 도 Cronbach's $\alpha$ 에 의한 신뢰도 계수는 공격적. 반사회적 행동 .83 , 방해하는 행동 .87 , 파괴적 행 동 .87 , 감정적·의존적 행동 .87 , 사회적 활동의 기피 .87 이었다.

다. 교사의 문제행동 지도전략

유아 문제행동에 대한 교사의 지도전략을 알아 보기 위해서 김연하(2007)의 '교사용 유아 문제행 동 지도전략 척도(Teacher Strategy Questionnaire; $\mathrm{TSQ})^{\prime}$ 를 사용하였다. 이 도구는 긍정적 예방전략 I, II와 긍정적 반응전략 및 부정적 반응전략의 4 가지 하위영역으로 이루어져있다. 긍정적 예방전 략 I은 유아의 문제행동을 지도하기 위하여 물리 적 환경의 재배치 및 긍정적 행동 유도 등의 예 방적 차원의 지도전략을 의미하며, 긍정적 예방 전략 II는 명확한 일과계획 및 기대수준과 관련 된 지도전략을 의미한다. 긍정적 반응전략은 유 아가 문제행동을 보인 경우 적절한 반응이 무엇 인지를 알려주는 등의 지도전략을 사용하는 것을 의미하여, 부정적 반응전략은 유아가 문제행동을 보인 경우 문제행동을 지도하기 위하여 행동을 못하게 하거나 타임아웃 등의 지도전략 사용하는 정도를 의미한다. 본 척도는 총 34 문항으로 평소 교사가 각각의 지도전략을 얼마나 자주 사용하는 지에 대해 '전혀 사용하지 않는다(1점)' ’매우 자 주 사용한다(5점)'의 5점 척도로 평정하였다.

하위 영역별 문항 수 및 내적 합치도인 Cronbach's $\alpha$ 에 의한 신뢰도 계수는 긍정적 예방전략 $\mathrm{I}(11$ 문 항) .89 , 긍정적 예방전략 $\mathrm{II}(7$ 문항) .81 , 긍정적
반응전략(9문항) .83 , 부정적 반응전략(7문항) .73 이었다.

\section{3. 연구 절차}

본 연구의 자료 수집을 위하여 연구의뢰에 동 의한 $\mathrm{B}$ 지역에 유치원 18 곳과 어린이집 6 곳에서 근무하는 유아교사 300 명에게 우편과 방문을 통 해 설문지를 배부하였다. 설문지 배부 2주 뒤 수 집된 설문지 중 응답이 부적절한 설문지 32부를 제외한 268부를 1차적으로 분석에 사용하였다. 1 차적으로 수집된 268명의 자료 중 유아교사의 전 문성발달 수준의 총점을 기준으로 상위 $33 \%$, 하 위 $33 \%$ 의 자료가 선정되어 176 부의 설문지가 최 종적으로 분석에 사용되었다.

\section{4. 자료 분석}

본 연구에서 수집된 자료는 SPSS 18.0을 사용 하여 다음과 같은 분석되었다. 먼저 연구대상의 일반적 특징을 알아보기 위하여 빈도와 백분율을 산출하였고 연구도구의 신뢰도를 알아보기 위하 여 Cronbach's $\alpha$ 를 산출하였다. 연구문제 1, 2 와 관련하여 유아교사의 전문성 발달수준에 따른 유아의 문제행동인식 및 문제행동 지도전략의 차 이를 알아보기 위해 일원분산분석(one-way ANOVA) 를 실시하였다. 연구문제 3 과 관련하여 교사의 전문성 발달수준에 따른 유아의 문제행동인식과 문제행동 지도전략 간의 관계를 살펴보기 위해 집단별 적률상관분석을 실시하였다.

\section{III. 연구 결과 및 해석}

\section{1. 유아교사의 전문성 발달수준에 따른 문 제행동인식의 차이}

유아교사의 전문성 발달수준에 따라 유아 문제 행동에 대한 교사인식에 차이가 있는지를 살펴본 결과는 <표 2>에 제시하였다. 
<표 2> 유아교사의 전문성 발달수준에 따른 문 제행동에 대한 인식의 차이검증

\begin{tabular}{|c|c|c|c|}
\hline 변인 & 집단 & $M(S D)$ & $F$ \\
\hline \multirow{3}{*}{$\begin{array}{l}\text { 공격적 · } \\
\text { 반사회적 행동 }\end{array}$} & 상 $(n=88)$ & $3.90(.55)$ & \multirow{3}{*}{$15.71^{* \star * t}$} \\
\hline & 하 $(n=88)$ & $3.61(.46)$ & \\
\hline & 전체 & $3.77(.52)$ & \\
\hline \multirow{3}{*}{ 방해하는 행동 } & 상 $(n=88)$ & $3.83(.72)$ & \multirow{3}{*}{$6.48^{\text {*k }}$} \\
\hline & 하 $(n=88)$ & $3.58(.67)$ & \\
\hline & 전체 & $3.70(.68)$ & \\
\hline \multirow{3}{*}{ 파괴적 행동 } & 상 $(n=88)$ & $3.81(.66)$ & \multirow{3}{*}{$8.60^{\text {** }}$} \\
\hline & 하 $(n=93)$ & $3.53(.64)$ & \\
\hline & 전체 & $3.68(.66)$ & \\
\hline \multirow{3}{*}{$\begin{array}{l}\text { 감정적 · 의존적 } \\
\text { 행동 }\end{array}$} & 상 $(n=88)$ & $3.17(.62)$ & \multirow{3}{*}{.42} \\
\hline & 하 $(n=88)$ & $3.12(.49)$ & \\
\hline & 전체 & $3.14(.55)$ & \\
\hline \multirow{3}{*}{$\begin{array}{l}\text { 사회적 활동의 } \\
\text { 기피행동 }\end{array}$} & 상 $(n=88)$ & $3.46(.63)$ & \multirow{3}{*}{3.57} \\
\hline & 하 $(n=88)$ & $3.30(.54)$ & \\
\hline & 전체 & $3.37(.59)$ & \\
\hline
\end{tabular}

먼저 <표 2>에서 알 수 있듯이, 연구대상 유아 교사가 5 가지 문제행동에 대해 문제라고 인식하 는 정도는 문항평균 3.14 3.77로 1 5점의 점수범 위를 고려하건대, 모든 행동에 대하여 중간 이상 으로 문제라고 생각하고 있었다. 하위 영역별로 볼 때 유아의 공격적·반사회적 행동을 가장 높게 문제라고 인식하였으며, 감정적.의존적 행동을 가 장 낮은 정도로 문제라고 인식하고 있었다.

다음으로 유아교사의 전문성발달 수준에 따라 문제행동 인식에서의 차이를 살펴본 결과 공격 적·반사회적 행동, 방해하는 행동, 파괴적 행동에 대한 인식에서 유의한 차이가 있었다. 전문성 발 달수준이 상집단 $(\mathrm{M}=3.90)$ 인 교사가 하집단 $(\mathrm{M}=3.60)$ 교사보다 유아의 공격적.반사회적 행동을 더 문 제행동이라고 인식하고 있었다 $(\mathrm{F}=15.71, \mathrm{p}<.001)$. 방해하는 행동은 교사의 전문성 발달수준이 상집 단 $(\mathrm{M}=3.83)$ 교사가 하집단 $(\mathrm{M}=3.58)$ 보다 더 문제 행동이라고 인식하였다 $(\mathrm{F}=6.48, \mathrm{p}<.01)$. 또한, 파 괴적 행동의 경우 전문성 발달수준이 상집단 $(\mathrm{M}=3.81)$ 인 교사가 하집단 $(\mathrm{M}=3.53)$ 에 비해 더 문제행동이라고 응답하였다 $(\mathrm{F}=8.61, \mathrm{p}<.01)$. 하지
만 유아의 감정적·의존적 행동 및 사회적 활동의 기피행동을 문제라고 보는 인식 정도는 교사의 전문성 발달수준에 따라 차이가 없었다.

\section{2. 유아교사의 전문성 발달수준에 따른 문 제행동 지도전략의 차이}

유아교사의 전문성 발달수준에 따라 교사의 문 제행동 지도전략에 차이가 있는지를 살펴볼 결과 를 <표 3>에 제시하였다.

<표 3> 유아교사의 전문성 발달수준에 따른 문 제행동 지도전략의 차이검증

\begin{tabular}{|c|c|c|c|}
\hline 변인 & 집단 & $M(S D)$ & $F$ \\
\hline \multirow{3}{*}{$\begin{array}{l}\text { 긍정적 } \\
\text { 예방전략 I }\end{array}$} & 상 $(n=88)$ & $3.95(.44)$ & \multirow{3}{*}{$170.15^{\star k+*}$} \\
\hline & 하 $(n=88)$ & $3.16(.39)$ & \\
\hline & 전체 & $3.59(.60)$ & \\
\hline \multirow{3}{*}{$\begin{array}{l}\text { 긍정적 } \\
\text { 예방전략 П }\end{array}$} & 상 $(n=88)$ & $4.24(.42)$ & \multirow{3}{*}{$113.56^{\text {sth }}$} \\
\hline & 하 $(n=88)$ & $3.58(.44)$ & \\
\hline & 전체 & $3.93(.55)$ & \\
\hline \multirow{3}{*}{$\begin{array}{l}\text { 긍정적 } \\
\text { 반응전략 }\end{array}$} & 상 $(n=88)$ & $4.24(.39)$ & \multirow{3}{*}{$107.60^{\text {** }}$} \\
\hline & 하 $(n=88)$ & $3.60(.45)$ & \\
\hline & 전체 & $3.94(.55)$ & \\
\hline \multirow{3}{*}{$\begin{array}{l}\text { 부정적 } \\
\text { 반응전략 }\end{array}$} & 상 $(n=88)$ & $3.23(.62)$ & \multirow{3}{*}{2.11} \\
\hline & 하 $(n=88)$ & $3.12(.48)$ & \\
\hline & 전체 & $3.21(.59)$ & \\
\hline
\end{tabular}

<표 3>에서 알 수 있듯이 유아교사의 문제행 동 지도전략의 문항평균은 3.21 3.94로, 1 5점의 점수범위를 고려하건대 교사들이 모든 문제행동 지도전략을 중간이상 사용하고 있었다. 긍정적 예방전략 II와 긍정적 반응전략을 다른 지도전략 보다 좀 더 많이, 부정적 반응전략을 더 적게 사 용하는 것으로 나타났다.

다음으로 유아의 문제행동에 대한 교사의 지도 전략은 부정적 반응전략을 제외한 모든 하위영역 에서 유아교사의 전문성 발달수준에 따라 유의미 한 차이가 있었다. 즉, 전문성 발달수준이 상집단 $(\mathrm{M}=3.95)$ 인 교사는 하집단 $(\mathrm{M}=3.16)$ 보다 문제행동 을 지도하기 위하여 물리적 환경을 재배치하는 
등의 긍정적 예방전략 $\mathrm{I}$ 을 더 많이 사용하였다 $(\mathrm{F}=170.15, \mathrm{p}<.001)$. 또한 전문성 발달수준이 상 집단(M=4.24)인 교사는 하집단 $(\mathrm{M}=3.58)$ 보다 유아 의 문제행동을 지도하기 위하여 일과계획을 분명 히 하고 기대수준을 명확히 하는 등의 긍정적 예 방전략 II를 더 많이 실시하였다 $(\mathrm{F}=113.56, \mathrm{p}<.001)$. 또한, 전문성 발달수준이 상집단 $(\mathrm{M}=4.24)$ 교사가 하집단 $(\mathrm{M}=3.60)$ 보다 유아의 문제행동을 지도하기 위하여 적절한 대안행동을 알려주는 것과 같은 긍정적 반응전략을 더 많이 사용하였다 $(\mathrm{F}=107.60$, $\mathrm{p}<.001)$. 하지만 유아가 문제행동을 보였을 때 이를 지도하기 위한 교사의 부정적 반응전략은 교사의 전문성발달수준에 따라 차이가 없었다.

\section{3. 유아교사의 전문성 발달수준에 따른 문 제행동인식 및 문제행동지도전략의 상관 관계}

유아교사의 전문성 발달수준에 따라 유아의 문 제행동에 대한 교사인식과 지도전략 간의 관계가 어떠한지를 알아보기 위하여 전문성발달 상, 하 집단별로 두 변인간의 적률상관계수를 산출한 결 과는 <표 $4>$ 에 제시하였다.

<표 4>에서 알 수 있듯이 전문성 발달수준이 상집단인 교사는 유아의 공격적. 반사회적 행동
을 문제행동이라고 인식할수록 긍정적 예방전략 $\mathrm{I}(\mathrm{r}=.25, \mathrm{p}<.05)$, 긍정적 예방전략 $\Pi(\mathrm{r}=.26, \mathrm{p}<.05)$, 긍정적 반응전략 $(\mathrm{r}=.33, \mathrm{p}<.01)$ 을 더 많이 사용하 였다. 또한 전문성발달 수준이 상집단인 교사들 은 방해하는 행동을 문제라고 인식할수록 긍정적 예방전략 I $(\mathrm{r}=.24, \mathrm{p}<.05)$, 파괴적 행동을 문제라 고 인식할수록 긍정적 예방전략 $\mathrm{I}(\mathrm{r}=.25, \mathrm{p}<.05)$ 과 긍정적 반응전략 $(\mathrm{r}=.24, \mathrm{p}<.05)$ 을, 감정적.의존 적 행동을 문제라고 인식할수록 긍정적 예방전략 $\mathrm{I}(\mathrm{r}=.28, \mathrm{p}<.01)$ 과 긍정적 반응전략 $(\mathrm{r}=.28, \mathrm{p}<.01)$ 을, 사회적 활동의 기피행동을 문제라고 인식할 수록 긍정적 반응전략 $(\mathrm{r}=.22, \mathrm{p}<.05)$ 을 많이 사용 하였다.

반면, 전문성 발달수준이 하집단인 교사들은 유아의 공격적·반사회적 행동을 문제행동

이라고 인식할수록 긍정적 반응전략 $(r=.25, p$ $<.05)$ 을, 방해하는 행동을 문제라고 인식할수 록 긍정적 반응전략 $(r=.22, p<.05)$ 과 부정적 반 응전략 $(r=.23, p<.05)$ 을 사용하는 것으로 나타 났다. 또한 전문성 발달수준이 하집단인 교사 들은 유아의 파괴적 행동을 문제라고 인식할수 록 긍정적 예방전략 $\mathrm{I}(r=.21, p<.05)$ 및 긍정적 반응전략 $(r=.21, p<.05)$ 과 부정적 반응전략 $(r=.26, p<.05)$ 을 많이 사용하였다. 사회적 활

<표 $4>$ 유아교사의 전문성발달수준에 따른 문제행동인식과 문제행동지도전략의 적률상관계수

\begin{tabular}{|c|c|c|c|c|c|}
\hline \multicolumn{2}{|r|}{ 변 인 } & $\begin{array}{c}\text { 긍정적 } \\
\text { 예방전략 I }\end{array}$ & $\begin{array}{c}\text { 긍정적 } \\
\text { 예 방전략 } \Pi\end{array}$ & $\begin{array}{c}\text { 긍정적 } \\
\text { 반응 전략 }\end{array}$ & $\begin{array}{c}\text { 부정적 } \\
\text { 반응 전략 }\end{array}$ \\
\hline \multirow{5}{*}{$\begin{array}{l}\text { 상집단 } \\
(n=88)\end{array}$} & 공격적 · 반사회적 행동 & $.25^{*}$ & $.26^{*}$ & $.33^{* *}$ & .06 \\
\hline & 방해하는 행동 & $.24^{*}$ & .07 & .15 & .02 \\
\hline & 파괴적 행동 & $.25^{*}$ & .18 & $.24^{*}$ & .03 \\
\hline & 감정적·의존적행동 & $.28^{* * *}$ & .12 & $.28^{* *}$ & .06 \\
\hline & 사회적 활동의 기피행동 & .17 & .05 & $.22^{*}$ & .01 \\
\hline \multirow{5}{*}{$\begin{array}{l}\text { 하집단 } \\
(n=88)\end{array}$} & 공격적 · 반사회적 행동 & .18. & .16 & $.25^{*}$ & .15 \\
\hline & 방해하는 행동 & .18 & .18 & $.21^{*}$ & $.23^{*}$ \\
\hline & 파괴적 행동 & $.21^{*}$ & .17 & $.21^{*}$ & $.26^{*}$ \\
\hline & 감정적·의존적행동 & .17 & -.05 & .10 & .05 \\
\hline & 사회적 활동의 기피행동 & $.28^{* *}$ & .09 & .14 & $.26^{*}$ \\
\hline
\end{tabular}


동의 기피행동을 문제라고 인식할수록 긍정적 예방전략 $\mathrm{I}(r=.28, p<.01)$ 과 부정적 반응전략 $(r=.26, p<.05)$ 을 많이 사용하였다. 반면, 전문 성 발달수준이 낮은 교사의 경우 감정적 - 의존 적 행동을 문제라고 인식하는 것과 문제행동 지도전략은 아무런 관련성을 보이지 않았다.

요약컨대, 문제행동의 하위영역별로 다소 차이 가 있었으나 대체적으로 전문성 발달수준이 높은 집단의 교사들은 각 문제행동을 문제라고 인식하 는 것과 긍정적 예방전략 $\mathrm{I}$, 긍정적 반응전략과 대체로 유의한 관련성을 보인 반면, 전문성 발달 수준이 낮은 집단의 교사들은 각 문제행동을 문 제라고 인식하는 정도와 긍정적 반응전략 및 부 정적 반응전략과 대체로 유의한 관련성을 보였 다. 다시 말해서 전문성 발달수준 상집단의 교사 의 경우 문제행동에 대한 인식과 교사의 부정적 반응전략 간의 관계가 유의하지 않았다. 반면, 전 문성 발달수준 하집단 교사는 문제행동에 대한 인식과 긍정적 예방전략 II와 유의한 관계를 보 이지 않아, 유아 교사의 전문성 발달수준에 따라 유아교사의 문제행동인식과 지도전략 간의 관계 가 다소 다르게 나타났다.

\section{IV. 논의 및 결론}

본 연구는 유아기 문제행동지도의 중요성을 고 려하여 유아교사의 문제행동지도전략에 대한 포 괄적 이해를 하고자 유아교사의 전문성 발달수준 에 따라 유아의 문제행동을 어떻게 인식하고 있 으며, 문제행동 지도전략은 어떠한지를 살펴보았 다. 나아가 유아교사의 전문성 발달수준에 따라 문제행동인식과 지도전략 간의 상관관계가 어떠 한지를 알아보고자 하였다. 본 연구에서 제시된 연구문제를 중심으로 주요결과를 요약하고 논의 하면 다음과 같다.

연구문제 1 과 관련하여 먼저 유아교사의 전문 성 발달수준에 따라 유아의 문제행동에 대한 교
사 인식을 알아본 결과, 전문성 발달수준이 높은 교사가 낮은 교사보다 유아의 공격적·반사회적 행동, 방해하는 행동, 파괴적 행동을 더 문제라고 인식하고 있었다. 이는 교육경력이 높은 교사들 이 유아의 부적절한 행동에 대해서 좀 더 문제가 된다고 인식한다고 제안한 이진경(2001), 김경숙 (2008)의 연구와 맥락을 같이 하는 결과라고 볼 수 있다. 교육경력이 바로 전문성발달을 의미하 는 것이 아닐지라도 교직주기의 발달단계에 대한 연구들(박은혜, 2009)을 고려할 때, 교직경력은 교사의 전문성발달에 긍정적 영향을 보일 수 있 을 것이다. 본 연구에서 교직경력에 따라 유아교 사의 전문성발달수준에 차이를 살펴본 추후분석 결과 교사의 교직경력에 따라 전문성 발달수준에 차이가 나타나 $(\mathrm{F}=6.56, \mathrm{p}<.001)$, 이러한 해석을 뒷 받침하여 주었다.

김경숙(2008)은 교사가 경력이 많아지면서 학 급운영과 유아와의 관계경험이 더 많아지게 되고 유아의 부적절한 행동을 더 예민하게 관찰할 수 있게 됨에 따라, 유아의 부적절한 행동을 더 자 주 인식하게 되고 이러한 행동이 교육기관에서 생활하는 유아에게 문제가 된다고 여길 수 있다 고 하였다. 전문성 발달수준이 높은 교사는 바람 직한 교수기술과 지식, 교사자신의 발달특성에 대한 이해 및 자신을 둘러싼 조직과 인간관계가 더 긍정적인 교사라고 할 수 있다(백은주·조부경, 2004). 이러한 선행연구들을 고려할 때 전문성 발 달수준이 높은 교사는 그렇지 않은 교사보다 유 아를 더 잘 이해하는 교사이며, 그 결과 유아의 공격적·반사회적 행동, 방해하는 행동, 파괴적 행 동과 같은 바람직하지 않은 행동을 더 문제라고 인식하고 있다고 해석해 볼 수 있다.

한편, 유아문제행동 유형 중 감정적.의존적 행 동, 사회적 활동의 기피행동에 대하여서는 교사 의 전문성 발달수준에 따라 유의미한 차이가 없 었다. Sterba, Prinstein과 $\operatorname{Cox}(2007)$ 에 따르면 교 사들은 유아의 공격성과 같은 외현화 문제행동보 다 위축행동과 같은 내면화 문제가 눈에 덜 띄기 
때문에 교사들은 유아가 내면화 행동의 어려움을 덜 경험할 것이라고 생각한다고 하였다. 즉, 위축 행동과 같은 내면화 행동은 유아기에 덜 문제가 된다고 인식하는 경향이 있다고 하였다. 이러한 입장에서 볼 때 교사들은 이시기 유아가 의존적 이거나 사회적 활동을 기피하는 것과 같은 내면 화 문제행동을 보이는 것에 대하여 공격성이나 파괴하는 행동과 같이 타인을 방해하는 행동보다 는 덜 심각하게 인식하고 있으며, 그 결과 전문성 발달수준에 따라서도 차이가 나타나지 않은 것으 로 유추해 볼 수 있다. 이러한 해석은 본 연구에 서 5 가지 문제행동에 대한 문항평균에서 감정적. 의존적 행동, 사회적 활동의 기피행동에 대한 점 수가 가장 낮게 나타난 결과와 맥락을 같이한다.

다음으로 연구문제 2 와 관련하여 유아교사의 전문성 발달수준에 따라 문제행동지도전략에도 차이가 있었다. 즉, 전문성 발달수준이 높은 교사 가 부정적 반응전략을 제외한 모든 문제행동지도 전략을 더 많이 사용하고 있는 것으로 나타났다. 구체적으로 전문성 발달수준이 높은 교사는 유아 의 문제행동을 지도하기 위하여 학급 내 환경의 재배치 등으로 긍정적인 행동을 유도하거나 명확 한 일과계획 및 기대 수준을 제시하는 것과 같은 긍정적 예방 전략 I, II 뿐 아니라 바람직한 방법 으로 행동했을 때 적극적인 칭찬과 관심을 보임 으로써 문제행동을 감소시키는 것과 같은 긍정적 반응전략을 더 많이 사용하였다.

유아교사의 전문성발달 수준에 따른 문제행동 지도전략의 차이를 살펴본 선행연구가 전무하여 직접적인 비교는 하기 어렵지만, 본 연구 결과는 유아교사의 경력에 따라 문제행동지도전략의 차 이를 나타낸 김경숙(2008)의 연구와 맥락을 같이 하는 결과이다. 김경숙(2008)의 연구에서 교육경 력이 적은 교사는 환경 재배치 및 긍정적 행동 유도와 관련된 긍정적 예방전략 I 과 명확한 일과 계획 및 기대 수준과 관련된 긍정적 예방전략 II 을 상대적으로 적게 사용하였다. 김선희와 백은 주(2010)는 유치원 교사의 전문성 발달수준을 높
이는 멘토링을 통해 교사는 유아에게 적절한 교 육활동을 계획하고 환경을 구성할 뿐 아니라 유 아와의 직접적 상호작용이 증진됨으로써 교육의 질이 높일 수 있다고 하였다. 이 연구가 유아교 사의 전문성발달수준에 따른 문제행동지도전략을 살펴본 것은 아니지만, 이러한 견해를 바탕으로 볼 때 전문성 발달수준이 높은 교사는 유아에게 적절한 교육활동을 제시하고 유아와 적절한 상호 작용을 계획하고 실시할 수 있는 교사라고 할 수 있다. 따라서 교실에서 유아가 문제행동을 보일 경우 자신감을 가지고 긍정적 예방전략 뿐 아니 라 긍정적 반응전략과 같은 바람직한 지도전략을 더 많이 사용하게 된다고 유추해 볼 수 있다.

마지막으로 연구문제 3과 관련하여 유아교사의 전문성 발달수준에 따른 유아의 문제행동에 대한 교사인식과 지도전략의 관계가 어떠한지를 살펴 본 결과, 유아교사의 전문성 발달수준에 따라 교 사의 문제행동에 대한 인식과 지도전략의 관계에 서 차이가 있었다. 구체적으로 교사의 전문성 발 달수준이 높은 경우 유아의 공격적·반사회적 행 동을 문제라고 생각할수록 교사는 긍정적 예방전 략 I, II 및 긍정적 반응전략을 사용하였다. 다음 으로 방해하는 행동이 문제라고 생각할수록 긍정 적 예방전략 $\mathrm{I}$ 을, 파괴적 행동 및 감정적·의존적 행동을 문제라고 인식할수록 긍정적 예방전략 I 과 긍정적 반응전략을, 사회적 활동의 기피행동 을 문제라고 인식할수록 긍정적 반응전략을 사용 하였다. 또한 전문성 발달수준이 높은 교사는 문 제행동에 대한 인식과 교사의 부정적 반응전략 사용과 유의한 관계를 나타내지 않았다. 반면, 유 아교사의 전문성 발달수준이 낮은 경우 공격적. 반사회적 행동을 문제라고 생각할수록 긍정적 반 응전략을, 방해하는 행동이 문제라고 인식할수록 긍정적 반응전략 및 부정적 반응전략을, 파괴적 행동을 문제라고 인식할수록 긍정적 예방전략 I 및 긍정적 반응전략과 부정적 반응전략을 더 많 이 사용하였다. 교사의 전문성 발달수준이 낮은 경우 사회적 활동의 기피행동을 문제라고 보는 
인식은 교사의 긍정적 예방전략 I과 부정적 반응 전략과 유의한 관계를 보였다. 유아의 감정적·의 존적 행동에 대한 문제인식은 어떠한 지도전략과 도 관련성을 보이지 않았다. 요약컨대, 문제행동 의 하위영역에 따라 약간의 차이는 있었으나 전 문성발달수준이 높은 교사의 경우 문제행동에 대 한 인식과 긍정적 예방 전략이 유의한 정적 상관 을 보였으며, 부정적 반응전략 사용과는 관계가 없었다. 하지만, 전문성 발달수준이 낮은 교사의 경우 문제행동에 대한 인식이 예방적 전략, 특히 긍정적 예방전략 II와는 유의한 상관이 없었으며, 또한 문제행동에 대한 인식이 부정적 반응전략 사용과 유의한 상관관계를 나타내었다.

김미선과 송준만(2006)은 초등학생을 대상으로 한 연구에서 긍정적 행동지원을 통한 문제행동지 도가 이들의 문제행동 감소에 효과적이었다는 결 과를 토대로 아동의 문제행동을 지도하기 위하여 교사의 긍정적 행동지도가 중요함을 시사하였다. 전문성 발달수준 및 문제행동의 유형에 따라 다 소 차이가 있지만, 본 연구에서 유아의 문제행동 인식과 긍정적 예방전략 및 긍정적 반응전략 간 에 유의한 정적 관계를 보인 것은 이러한 견해를 지지하는 결과이다.

한편, 본 연구와 직접적인 관련성을 보이지는 않지만, 김지연(1997), 이은미(2002) 연구에 따르 면 유아교사의 전문성 발달수준이 높을수록 교사 는 유아교육기관 내에서 역할수행을 더 잘 하였 다. 이러한 선행연구를 고려할 때 전문성 발달수 준이 높은 교사는 교사로서 역할수행을 더 잘 수 행하게 되고, 그 결과 자신에 대해 높은 교수효 능감과 자신감을 경험하게 된다고 유추해 볼 수 있다. 이러한 관점에서 볼 때, 전문성 발달수준이 높은 집단의 교사들은 자신의 교수 효능감을 바 탕으로 유아의 행동을 문제행동이라고 인식하는 것이 적극적인 문제행동지도전략과 정적 상관관 계를 가지게 된다고 예상해 볼 수 있다. 따라서 교사의 문제행동에 대한 인식이 긍정적 예방 및 반응 전략으로 연계됨으로써 교사의 전문성 발달
수준이 낮은 집단보다 두 변인 간에 유의미한 상 관관계가 더 많이 나타난 것으로 해석해 볼 수 있다. 하지만 본 연구에서는 전문성수준이 높은 교사의 교수 효능감을 직접 살펴본 것은 아니므 로, 이러한 해석은 조심스럽게 이루어져야 할 것 이다. 전문성 발달수준이 높은 교사의 문제행동 인식 및 지도전략의 관계에서 교수효능감이 어떠 한 역할을 하는지는 추후 연구를 통해 더 알아보 아야 할 것이다.

본 연구에서 전문성 발달수준이 높은 교사와의 달리 전문성 발달수준이 낮은 교사의 경우 유아 의 방해하는 행동, 파괴하는 행동, 사회적 활동의 기피행동을 문제라고 인식하는 것은 교사의 부정 적 반응전략 사용과 유의한 정적 상관을 나타내 었다. 김경숙(2008)은 유아의 문제행동을 유아자 체의 문제로 인식할 경우 그 행동을 지도하기 위 하여 부정적 지도전략을 사용하게 된다고 하였 다. 이러한 관점에서 볼 때, 전문성 발달수준이 낮은 교사는 유아의 방해하는 행동, 파괴하는 행 동, 사회적 활동의 기피행동을 유아자체의 문제 라고 보고 이를 소거하기 위해 부정적 지도전략 을 사용하게 된다고 유추해 볼 수 있다. 더욱이 앞선 분석에서 교사의 전문성 발달수준에 따라 부정적 반응전략 사용의 평균차이는 유의하지 않 았으나, 전문성 발달수준이 낮은 교사의 경우에 만 유아의 문제행동에 대한 인식과 부정적 반응 전략 사용 간 유의한 상관관계가 나타났다. 이는 유아교사의 전문성 발달수준에 따라 교사의 유아 의 문제행동에 대한 인식이 지도전략과 관련되는 방식이 다름을 보여주는 것이다. 즉, 유아교사가 문제행동을 지도하기 위해 사용하는 부정적 반응 전략은 전문성 발달수준이 높은 교사나 낮은 교 사들 모두 보통정도로 사용하고 있었으나, 부정 적 반응전략 사용에 관련되는 요인은 유아교사의 전문성 발달수준에 따라 다르게 나타났다. 즉, 전 문성발달수준이 낮은 경우에는 유아의 문제행동 에 대한 교사인식이 부정적 반응전략 사용과 관 련되었지만, 전문성 발달수준이 높은 교사는 유 
아의 문제행동에 대한 인식이 부정적 반응전략과 관련되는 것이 아니었다. 전문성 발달수준이 높 은 교사의 경우 유아의 문제행동에 대한 부정적 반응지도전략과 관련된 요인이 무엇인지에 대하 여서는 추후 연구를 통해 살펴보아야 할 것이다.

결론적으로 유아교사의 전문성 발달수준에 따 라 유아문제행동인식 및 문제행동지도전략에 차 이가 있었으며, 전문성 발달수준에 따라 유아문 제행동인식과 문제행동지도전략 간의 상관관계가 다소 다르게 나타났다. 이는 유아의 문제행동에 대한 이해 및 문제행동지도전략에 대한 교사교육 계획 시 교육받는 유아교사의 전문성 발달수준에 따라 교사교육 내용을 달리해야 할 필요가 있음 을 시사해 준다.

본 연구의 제한점 및 추후연구를 위한 제언을 하면 다음과 같다. 첫째 본 연구는 B시에 근무하 는 유아교사만을 대상으로 표집되어 본 연구결과 를 모든 유아교사에게 일반화하기에는 제한이 따 른다. 이에 추후연구에서는 전국단위의 유아교사 를 대상으로 알아볼 필요가 있다. 또한 본 연구 에서는 유아반 이상의 교사만을 대상으로 하였으 나, 최근 무상보육, 맞벌이가정 증가 등의 이유로 영아의 어린이집 재원이 확대되는 것을 고려할 때, 영아반 교사를 대상으로 영아의 문제행동에 대한 인식 및 영아반 교사의 문제행동지도전략을 살펴보는 연구가 필요할 것이다.

이러한 제한점에도 불구하고 본 연구는 김경숙 (2008)이 유아문제행동인식과 반응적 지도전략 간의 관계만을 살펴본 것에서 나아가 유아교사의 전문성발달수준에 따라 유아의 문제행동에 대한 인식과 예방적 및 반응적 지도전략이 어떻게 달 라지는지를 살펴봄으로써 유아교사의 문제행동지 도전략에 대한 이해의 폭을 넓히고, 이들을 위한 교사교육의 방안마련에 기초를 제공하였다는 점 에서 그 의의를 찾을 수 있다.

\section{참고 문헌}

강미라(2005). 유아교사의 자아개념과 교사효능감 과의 관계연구, 경희대학교대학원 석사학위논 문.

강정원 - 이경민(2006). 유아의 초등학교 적응을 위한 전이 프로그램의 운영 실태, 유아교육학 논집 10, 311 337.

강현경 - 조형숙(2008). 유아의 문제행동에 관한 부모-교사 평가 간의 차이비교, 유아교육학논집 12, 171 193.

권혜영(2006). 유치원의 조직풍토, 전문성지원환 경과 교사효능감과의 관계, 경희대학교대학원 석사학위논문.

김경숙(2008). 유아 문제행동에 대한 교사의 인식 및 대처전략, 이화여자대학교대학원 석사학위 논문.

김광웅(2002). 유아행동지도, 서울: 교육과학사.

김미선 · 송준만(2006). 학교차원의 긍정적 행동지 원이 초등학교 학생들의 문제행동과 학교 분위 기에 미치는 영향, 특수교육학연구 1(3), 207 227. 김선희 - 백은주(2010). 유치원 교사의 전문성 발 달을 돕는 멘토링의 효과, 대한가정학회지 48(9), 69 78.

김연하(2007). 유아 문제행동 지도전략 척도-교사 용(TSQ)의 개발과 타당화 연구, 아동학회지 28(5), 73 89.

김영아 - 이진 · 김유진 · 김민영 · 오경자(2011). 한 국판 유아행동평가척도 교사용(C-TRF)의 표준 화연구, 한국심리학회지: 발달 24(2), 65 86.

김준규 - 박희숙 · 추성경(2005). 유아생활지도, 서 울: 동문사.

김지연(1997). 어린이집 보육교사의 교직전문성 인식과 역할수행과의 관계, 이화여자대학교대 학원 석사학위논문.

김지영(2002). 교사가 인식한 유아의 문제 행동과 문제 유형별 지도에 관한 조사 연구, 성균관대 학교대학원 석사학위논문.

김현정(2000). 유아교육기관 부적응 아동과 지도 에 대한 교사의 인식조사, 계명대학교대학원 석사학위논문.

박은혜(2009). 유아교사론, 서울: 창지사.

백은주 - 조부경(2004). 유치원 교사의 전문성 발 달수준 자기평가 도구 개발, 아동교육연구 24(4), 95 117. 
성병창(2007). 초임교사 교직적응을 위한 지원방 안, 수해양교육연구 19(2), 310 322.

성병창 - 부재율 - 한경임 - 이경화(2009). 교사의 핵 심역량에 대한 교육공동체의 인식조사, 수산해 양교육연구 21(1), 78 95.

신미숙(2004). 조기교육과 유치원교육에 대한 학 부모의 견해: 유아기자녀를 둔 어머니들을 대 상으로, 경남대학교대학원 석사학위논문.

이은미(2002). 유아교육 교사의 교직전문성 인식, 정보 자원 활용, 교사역할수행의 관계 연구, 카 톨릭대학교대학원 석사학위논문.

이진경(2001). 아동의 위축행동에 관한 유아교사 의 인식 및 실태조사, 중앙대학교대학원 석사 학위논문.

임우정(2005). 유아교사의 배경변인과 심리적 변 인이 교사효능감에 미치는 영향, 숭실대학교대 학원 석사학위논문.

조부경 - 백은주(2004). 유치원 교사의 전문성 발 달 수준 자기평가 도구 개발, 유아교육연구 24(4), 95 117.

Essa, E. L.(1988). 유아행동지도, 지성애 역(원본 출판일 1983), 서울: 양서원.

Fox, L. Dunlap, G., \& Powell, D.(2002). Young children with challenging behavior: Issues and considerations for behavior support, Journal of positive behavior interventions 4, 208 217.

Lewis. T. J., Colvin, G., \& Sugai, G. (2000). The effects of pre-correction and active supervision on the recess behavior of elementary students, Education and Treatment of Children 23, 109 121.

Qi, C. H., \& Kaiser, A. P. (2003). Behavior problems of preschool children from low-income families: Review of the literature, Topics in Early Childhood Special Education 23(4), 188 216. Smith, S. C. (2004). The effects of targeted positive behavior support strategies on preschoolers externalizing behavior, Unpublished doctoral dissertation, University of Missouri- Columbia.

Sterba, S. K., Prinstein, M. J., \& Cox, M. K. (2007). Trajectories of internalizing disorders across childhood: Heterogeneity, external validity, and gender differences, Development and Psychopathology 19, 345-366.

VanDerHeyden, A. M., Witt, J. C., \& Gatti, S. (2001). Research into practice: Descriptive assessment method to reduce overall disruptive behavior in a preschool classroom, School Psychology Review 30, 548 567.

- 논문접수일 : 2012년 11월 05일

- 심사완료일 : 1차 - 2012년 12월 03일 2차 - 2013년 01월 13일

- 게재확정일 : 2013년 01월 16일 